\title{
Efek Iritasi Sabun Mandi Batang Mengandung Susu Produk Usaha Kecil Menengah di Kota Cimahi
}

\section{Iritation Effect of Bar Soap Containing Milk Produced by Small and Medium Enterprises in Cimahi}

\author{
Suci Nar Vikasari ${ }^{1}{ }^{*}$, Faizal Hermanto $^{1}$, Elivas Simatupang ${ }^{2}$, Afifah Bambang Sutjiatmo ${ }^{1}$, Titta \\ Hartyana Sutarna ${ }^{I}$, Ririn Puspadewi ${ }^{I}$, Lucky Rachmawan ${ }^{1}$, Fahmi Ahsanul Haq ${ }^{I}$ \\ ${ }^{I}$ Program Studi Sarjana Farmasi, Fakultas Farmasi, Universitas Jenderal Achmad Yani, Cimahi, Indonesia \\ ${ }^{2}$ Badan Penelitian dan Pengembangan Kota Cimahi, Cimahi, Indonesia \\ *E-mail: suci.vikasari@lecture.unjani.ac.id
}

\begin{abstract}
Abstrak
Salah satu cara meningkatkan keuntungan usaha kecil dan menengah (UKM) Kota Cimahi adalah dengan diversifikasi produk melalui pembuatan sabun batang yang berasal dari susu sapi hasil UKM. Sabun mandi batang harus mempunyai tingkat keasaman $(\mathrm{pH})$ yang tepat, bila tidak akan membuat kulit kering, gatal atau bahkan akan mengalami iritasi. Oleh karena itu dilakukan penelitian terhadap efek iritasi sabun mandi batang yang diproduksi UKM kota Cimahi dengan melakukan pengujian iritasi sesuai pedoman uji toksisitas nonklinik secara in vivo pada hewan uji tikus. Hewan uji dibagi menjadi lima kelompok dan dipaparkan sabun selama empat jam. Lima sampel sabun diperoleh dari UKM di kelurahan Cipageran, kota Cimahi. Pengamatan dilakukan pada jam ke-1,4, 24, 48 dan 72 jam setelah pemaparan dan dilanjutkan selama 14 hari. Parameter yang diamati adalah eritema dan udema, serta indeks iritasi primer. Hasil penelitian menunjukkan bahwa kelima sabun mandi yang mengandung susu sapi produksi UKM kota Cimahi tidak menyebabkan eritema dan udema. Hasil perhitungan indeks iritasi primer semua sampel sabun mandi sebesar 0,0. Berdasarkan hasil tersebut disimpulkan bahwa, sabun mandi batang mengandung susu sapi produksi UKM Kota Cimahi masuk kategori iritasi sangat ringan (negligigle).
\end{abstract}

Kata kunci: Sabun mandi; Susu; In vivo; Iritasi

\begin{abstract}
One of the ways to increase profit in small and medium business (UKM) in Cimahi is by diversifying its products, through manufacturing of bar soap derived from cow's milk from UKM. The requirement of bath soap is proper acidity $(\mathrm{pH})$ level, otherwise it will make the skin dry, itchy or even increase irritation. Therefore, this in vivo nonclinical irritation evaluation is conducted to evaluate the effects of bar soap produced by UKM in Cimahi according to the guidelines in rat test animals. The animals is divided into five groups and exposed to soap for four hours. Five soap samples is obtained from UKM in Cipageran area, Cimahi. Observations is made at the hours of 1, 4, 24, 48, and 72 hours after exposure and is continued for 14 days. The measured parameters is erythema and edema, and the primary irritation index. The results showed that bar soap containing cow milk produced by UKM in Cimahi did not cause erythema and edema. Primary irritation index of all bath soap samples was 0.0 . It can be concluded that soap bars containing cow's milk produced by Cimahi City UKM including into the category of very mild irritation (negligigle).
\end{abstract}

Keywords: Soap bar; Milk; In vivo; Irritation 


\section{PENDAHULUAN}

Salah satu cara yang dapat dilakukan untuk meningkatkan ekonomi masyarakat adalah diversifikasi produk olahan. Usaha susu perah di Indonesia juga melakukan diversifikasi untuk meningkatkan keuntungan, antara lain dengan membuat yoghurt, kefir, ataupun sabun batang yang mengandung susu. ${ }^{1,2}$ Beberapa usaha kecil dan menengah (UKM) di Kota Cimahi melakukan diversifikasi produk susu, salah satunya dengan menghasilkan sabun mandi batang. Pemilihan produk diversifikasi sabun mandi batang berdasarkan pertimbangan tingginya daya jual dan ketersimpanan produk dalam jangka waktu lama. ${ }^{3}$

Sabun mandi batang adalah kosmetik yang mengandung campuran bahan yang digunakan pada bagian luar badan, dengan tujuan untuk membersihkan, menambah daya tarik, mengubah penampakan, melindungi tubuh supaya tetap dalam keadaan baik, memperbaiki bau badan tetapi tidak dimaksudkan untuk mengobati atau menyembuhkan suatu penyakit. ${ }^{4}$ Susu sapi mengandung vitamin, mineral, antioksidan, protein, enzim dan lemak. Selain digunakan sebagai bahan pangan, susu sapi sering ditambahkan dalam pembuatan sabun mandi. Salah satu kandungan susu sapi, yaitu kasein. Kasein mempunyai gugus amfoter yang dapat menurunkan tegangan antar muka antara lemak dan air. Sifat kasein tersebut dapat digunakan untuk pembentukan dan penstabil emulsi, busa dan gel. ${ }^{5,6}$ Struktur amfoter pada kasein yang terkandung dalam susu juga dapat meningkatkan ketahanan pada epidermis kulit dan membantu regenerasinya. ${ }^{6}$ Keunggulan lain penggunaan sabun mandi yang mengandung susu karena susu mempunyai kemampuan retensi air yang tinggi dan mempunyai efek antibakteri. Efek antibakteri pada susu sapi dikarenakan kandungan protein dan enzim didalamnya (lisozim, laktoferin dan laktoperoksidase). ${ }^{6}$

Di Indonesia, kosmetik yang berupa sabun mandi, termasuk sabun mandi batang mengandung susu harus memenuhi persyaratan yang ditetapkan Standar Nasional Indonesia (SNI) No 3532:2016 mengenai sabun mandi padat. ${ }^{7}$ Retnowati dkk menyatakan bahwa sabun mandi mengandung susu yang beredar di Indonesia mempunyai kekurangan antara lain tekstur yang sangat lembek setelah digunakan dan nilai $\mathrm{pH}$ diatas $10,5^{\circ}$ Adanya $\mathrm{pH}$ tinggi pada sabun mandi dapat menyebabkan menurunnya flora normal kulit, menyebabkan pembesaran stratum korneum pada kulit, mengubah daya absorpsi kulit sehingga kulit mudah mengalami iritasi dan menjadi sensitif (alergi dan fotosensitivtas). ${ }^{8,9,10}$

Sabun mandi batang produksi UKM Cimahi dibuat menggunakan proses dingin saponifikasi, dimana akan terjadi hidrolisis alkali triasilgliserol dan bereaksi dengan basa kuat membentuk garam asam lemak, asam lemak bebas dan gliserol. ${ }^{11,12}$ Sabun mandi batang produksi UKM Cimahi dibuat menggunakan formula umum mengandung $10 \%$ susu sapi, $20 \%$ minyak kelapa, $20 \%$ minyak kelapa sawit, $10 \%$ kaustik soda $(\mathrm{NaOH})$, parfum dan ditambahkan air hingga $100 \%$. Derajat alkali yang tinggi pada sediaan sabun mandi padat dapat menyebabkan risiko terjadinya iritasi kulit. ${ }^{8,9,10}$ Oleh karena itu, pada penelitian ini dilakukan uji iritasi untuk mengetahui reaksi langsung yang timbul pada pemakaian pertama kosmetik karena dikhawatirkan sabun mandi batang produksi UKM Kota Cimahi bersifat iritan.

\section{METODE}

Penelitian ini merupakan penelitian eksperimental. Pengujian iritasi dermal sabun mandi susu Cipageran dilakukan berdasarkan Peraturan Kepala Badan Pengawas Obat dan Makanan Republik Indonesia Nomor 7 Tahun 2014 tentang Pedoman Uji Toksisitas Nonklinik secara In vivo. $^{13}$ Pengujian ini telah mendapat persetujuan Komite Etik Praklinik Institusional Nomor 6019/KEP-UNJANI/ VI/2019.

\section{Alat dan Bahan}

Alat yang digunakan antara lain timbangan hewan (Stanton 351BR ${ }^{\circledR}$ ), 
timbangan analitik (Shimadzu ATY $124^{\circledR}$ ),dan seperangkat alat uji iritasi.

Sampel berupa sabun mandi batang mengandung susu yang diperoleh dari UKM di Kelurahan Cipageran, Kecamatan Cimahi Utara, Kota Cimahi

Hewan uji yang digunakan pada penelitian ini adalah tikus Wistar jantan, usia 2 bulan dan bobot badan antara 180-200 gram. Hewan uji diperoleh dari Pusat Penelitian Biosains dan Biogenetika ITB. Hewan uji yang digunakan adalah hewan sehat yang ditandai dengan bulu putih dan tidak rontok.

\section{Prosedur kerja}

Pengumpulan sabun mandi batang

Sampel sabun mandi batang mengandung susu berasal dari Usaha Kecil Menengah (UKM) yang ada di Kelurahan Cipageran, Kecamatan Cimahi Utara, Kota Cimahi. Pengumpulan sampel sabun mandi berasal dari dua lokasi UKM, yaitu lokasi 1 dan lokasi 2. Pada UKM lokasi 1 diperoleh 3 sampel produk sabun batang, sedangkan pada UKM lokasi 2 diperoleh 2 sampel produk sabun batang (Gambar 1.). Sabun yang dikumpulkan adalah sabun yang baru saja diproduksi.

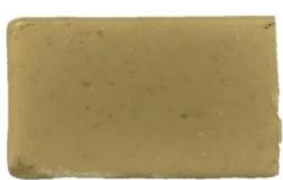

Sabun 1A

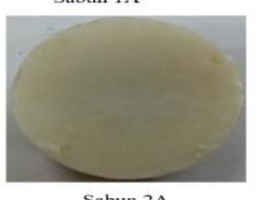

Sabun 2A

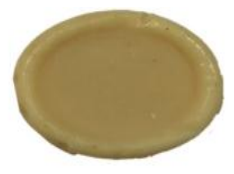

Sabun $1 \mathrm{~B}$

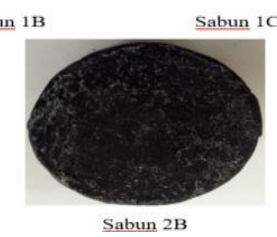

Gambar 1. Sampel sabun mandi batang mengandung susu dari UKM Kota Cimahi

Keterangan:

Sabun 1A,1B,dan 1C dari lokasi 1

Sabun 2A dan 2B dari lokasi 2

Pengujian iritasi sabun mandi

Pengujian iritasi dermal sabun mandi susu Cipageran dilakukan berdasarkan Peraturan Kepala Badan Pengawas Obat dan Makanan Republik Indonesia Nomor 7
Tahun 2014 tentang Pedoman Uji toksisitas Nonklinik secara In vivo. ${ }^{13}$

Sebelum dilakukan pengujian, hewan uji diaklimatisasi terlebih dahulu selama seminggu. Dua puluh empat jam sebelum pengujian, hewan uji dicukur di daerah punggung dan daerah punggung tersebut dibagi menjadi dua area untuk pemaparan sediaan uji dan kontrol. Sesuai dengan tahapan uji iritasi akut dermal yang tertera dalam Pedoman uji toksisitas nonklinik secara in vivo, maka hewan uji dibagi menjadi 5 kelompok (3 ekor per kelompok) yaitu kelompok yang diberi sampel sabun mandi batang 1a, 1b, 1c, 2a dan $2 \mathrm{~b} .{ }^{14}$

Sebanyak 0,5 gram sabun mandi padat yang dilarutkan dalam $15 \mathrm{ml}$ air diteteskan pada kain kasa dan dipaparkan pada kulit punggung hewan uji, dan pelarut air digunakan sebagai kontrol. Pemaparan zat uji dilakukan selama 4 jam, dimana pengamatan dilakukan pada jam ke-1 dan ke-4. Setelah zat uji dipaparkan selama 4 jam, kemudian dilakukan pelepasan zat uji. Untuk menghilangkan residu bahan uji, dilakukan penghilangan menggunakan air. Pengamatan iritasi dilakukan kembali pada jam ke-24, 48 dan 72 setelah pemaparan zat uji dan dilanjutkan selama tidak kurang 14 hari.

Parameter yang diamati adalah pembentukan eritema dan udema. Pengamatan parameter tersebut dilakukan menggunakan sistem skoring, dimana diberi skor 0 jika tidak ada eritema, skor 1 jika ada eritema yang sangat kecil dan hampir tidak dapat dibedakan, skor 2 jika eritema terlihat jelas, skor 3 jika eritema sedang sampai parah dan skor 4 jika eritema parah. Pengamatan udema juga dilakukan menggunakan sistem skoring, dimana diberi skor 0 jika tidak ada udema, skor 1 jika ada udema yang sangat kecil dan hampir tidak dapat dibedakan, skor 2 jika udema terlihat jelas, skor 4 jika udema sedang sampai parah dan skor 4 jika udema parah.

Untuk mengetahui tingkat keparahan luka dan ada tidaknya reversibilitas, maka dilakukan perhitungan indeks iritasi primer berdasarkan nilai skor eritema dan udema. 
Indeks Iritasi Primer $=\frac{\mathrm{A}+\mathrm{B}}{\mathrm{C}}$

$\mathrm{A}=$ Jumlah skor eritema dan udema seluruh titik pengamatan sampel pada jam ke 24 , 48 dan 72 dibagi jumlah pengamatan

$\mathrm{B}=$ Jumlah skor eritema dan udema seluruh titik pengamatan kontrol pada jam ke 24 , 48 dan 72 dibagi jumlah pengamatan

$\mathrm{C}=$ Jumlah hewan

\section{HASIL DAN PEMBAHASAN}

Pada penelitian ini, uji iritasi kulit dilakukan dengan mengamati adanya eritema dan udema setelah penggunaan sabun. Untuk mengurangi bias pada saat pengamatan dan pemberian skor eritema dan udema, maka pada penelitian ini disepakati dilakukan oleh tiga panelis. Hasil pengamatan uji iritasi dermal sediaan uji dapat dilihat pada Gambar 2 , hasil penilaian eritema dapat dilihat pada Tabel 1. dan 2, hasil penilaian udema dapat dilihat pada Tabel 3 dan 4 dan hasil perhitungan indeks iritasi primer dapat dilihat pada Tabel 5.

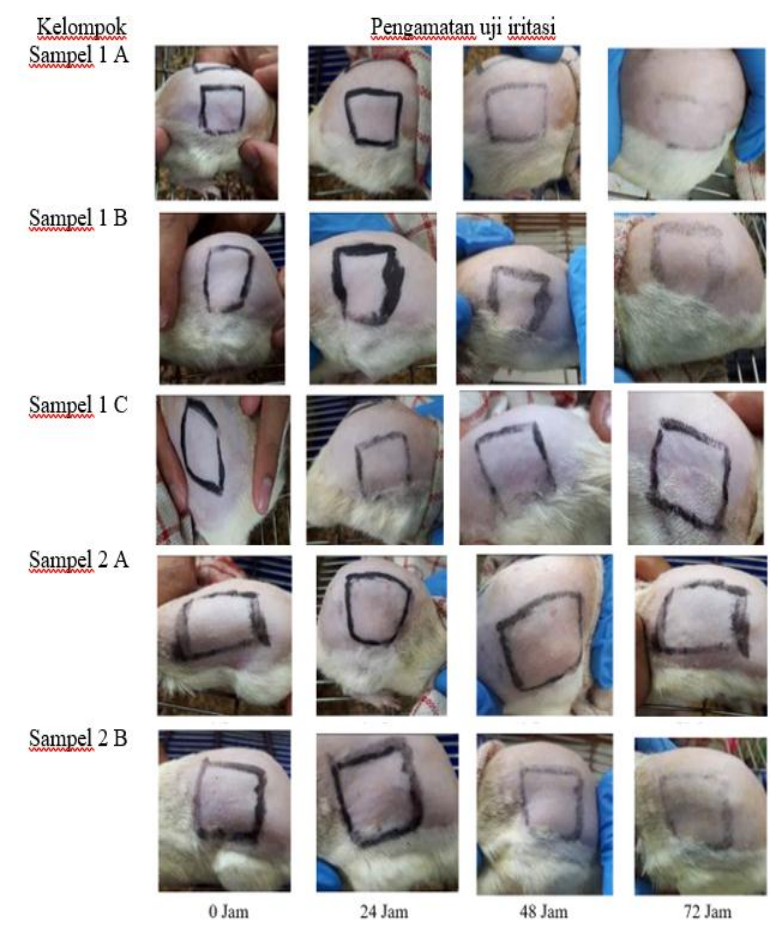

Gambar 2. Pengamatan uji iritasi sabun mandi batang mengandung susu dari UKM Kota Cimahi
Tabel 1. Hasil pengamatan eritema uji iritasi setelah pemaparan zat uji

\begin{tabular}{lccc}
\hline \multirow{2}{*}{ Kelompok } & \multicolumn{3}{c}{$\begin{array}{c}\text { Pengamatan eritema pada jam } \\
\text { ke- }\end{array}$} \\
\cline { 2 - 4 } & $\mathbf{2 4}$ & $\mathbf{4 8}$ & $\mathbf{7 2}$ \\
\hline Sampel 1A & 0,00 & 0,00 & 0,00 \\
Sampel 1B & 0,00 & 0,00 & 0,00 \\
Sampel 1C & 0,00 & 0,00 & 0,00 \\
Sampel 2A & 0,00 & 0,00 & 0,00 \\
Sampel 2B & 0,00 & 0,00 & 0,00 \\
\hline $\mathrm{n}=3$ & & &
\end{tabular}

Tabel 2. Hasil pengamatan eritema uji iritasi selama 14 hari setelah pemaparan zat uji

\begin{tabular}{lcccccc}
\hline \multirow{2}{*}{ Kelompok } & \multicolumn{6}{c}{ Pengamatan eritema pada hari ke- } \\
\cline { 2 - 7 } & $\mathbf{1}$ & $\mathbf{3}$ & $\mathbf{5}$ & $\mathbf{9}$ & $\mathbf{1 1}$ & $\mathbf{1 4}$ \\
\hline Sampel 1A & 0,00 & 0,00 & 0,00 & 0,00 & 0,00 & 0,00 \\
Sampel 1B & 0,00 & 0,00 & 0,00 & 0,00 & 0,00 & 0,00 \\
Sampel 1C & 0,00 & 0,00 & 0,00 & 0,00 & 0,00 & 0,00 \\
Sampel 2A & 0,00 & 0,00 & 0,00 & 0,00 & 0,00 & 0,00 \\
Sampel 2B & 0,00 & 0,00 & 0,00 & 0,00 & 0,00 & 0,00 \\
\hline $\mathrm{n}=3$ & & & & & &
\end{tabular}

Hasil pengamatan selama 72 jam dan 14 hari setelah pemaparan zat uji menunjukkan kelima sabun yang diproduksi UKM tidak menyebabkan eritema pada punggung kulit hewan uji

Tabel 3. Hasil pengamatan udema uji iritasi setelah pemaparan zat uji

\begin{tabular}{lccc}
\multirow{2}{*}{ Kelompok } & \multicolumn{3}{c}{ Pengamatan udema pada jam ke- } \\
\cline { 2 - 4 } & $\mathbf{2 4}$ & $\mathbf{4 8}$ & $\mathbf{7 2}$ \\
\hline Sampel 1A & 0,00 & 0,00 & 0,00 \\
Sampel 1B & 0,00 & 0,00 & 0,00 \\
Sampel 1C & 0,00 & 0,00 & 0,00 \\
Sampel 2A & 0,00 & 0,00 & 0,00 \\
Sampel 2B & 0,00 & 0,00 & 0,00 \\
\hline $\mathrm{n}=3$
\end{tabular}

$\mathrm{n}=3$

Tabel 4. Hasil pengamatan udema uji iritasi selama 14 hari setelah pemaparan zat uji

\begin{tabular}{lcccccc}
\hline \multirow{2}{*}{ Kelompok } & \multicolumn{9}{c}{ Pengamatan udema pada hari ke- } \\
\cline { 2 - 7 } & $\mathbf{1}$ & $\mathbf{3}$ & $\mathbf{5}$ & $\mathbf{9}$ & $\mathbf{1 1}$ & $\mathbf{1 4}$ \\
\hline Sampel 1A & 0,00 & 0,00 & 0,00 & 0,00 & 0,00 & 0,00 \\
Sampel 1B & 0,00 & 0,00 & 0,00 & 0,00 & 0,00 & 0,00 \\
Sampel 1C & 0,00 & 0,00 & 0,00 & 0,00 & 0,00 & 0,00 \\
Sampel 2A & 0,00 & 0,00 & 0,00 & 0,00 & 0,00 & 0,00 \\
Sampel 2B & 0,00 & 0,00 & 0,00 & 0,00 & 0,00 & 0,00 \\
\hline $\mathrm{n}=3$ & & & & & &
\end{tabular}

Hasil pengamatan selama 72 jam dan 14 hari setelah pemaparan zat uji menunjukkan kelima sabun yang diproduksi UKM tidak 
menyebabkan terbentuknya iritasi pada punggung kulit hewan uji

Tabel 5. Hasil perhitungan indeks iritasi primer

\begin{tabular}{lc}
\hline Kelompok & Nilai indeks iritasi primer \\
\hline Sampel 1A & 0,00 \\
Sampel 1B & 0,00 \\
Sampel 1C & 0,00 \\
Sampel 2A & 0,00 \\
Sampel 2B & 0,00 \\
\hline
\end{tabular}

Hasil perhitungan indeks iritasi primer kelima produk tersebut adalah 0 . Berdasarkan kriteria yang ada, jika nilai iritasi dalam rentang 0,0-0,4 maka sampel termasuk kategori iritasi sangat ringan (negligigle). ${ }^{13}$

Formula sabun batang pada sediaan yang diuji mengandung $\mathrm{NaOH}$. $\mathrm{NaOH}$ merupakan senyawa alkalin yang dapat meningkatkan $\mathrm{pH}$ kulit dan mengubah aktivitas enzim yang terlibat pada degradasi filaggrin yang berperan pada hidrasi stratum korneum pada kulit. $^{14}$ Pengaruh penambahan susu pada formula sabun batang dapat mengurangi efek yang tidak diharapkan dari $\mathrm{NaOH}$, karena susu mengandung kasein yang dapat bersifat surfaktan. $5,6,14$

Susu sapi mengandung $87 \%$ air, $3-4 \%$ lemak, 3,5\% protein, 5\% laktosa, dan 1,2\% mineral, dengan variasi tergantung tempat hewan diternakkan. ${ }^{17}$ Beberapa studi menyebutkan bahwa susu mengandung lisozim yang dapat bersifat antibakteri, bersifat proteolitik dan merupakan faktor imunoprotektif non spesifik. Selain lisozim, susu juga mengandung senyawa xanthin oksidase yang juga mempunyai efek antimikroba. Kasein yang terkandung dalam susu merupakan senyawa aktif permukaan yang dapat membantu hidrasi kulit. ${ }^{6}$ Pada penelitian ini, diduga kasein yang terkandung pada susu sapi yang ditambahkan pada sabun mandi batang dapat membantu tidak menyebabkan iritasi.

Fungsi kulit sebagai pertahanan tubuh berhubungan dengan sifat keasaman pada permukaan kulit ( $\mathrm{pH}$ permukaan kulit). Keasaman permukaan kulit tersebut rentan berubah, salah satunya karena penggunaan sabun dan produk pembersih kulit lainnya. Sabun yang baik untuk kulit adalah yang mempunyai $\mathrm{pH}$ normal atau $\mathrm{pH}>5 .{ }^{16,17}$ Pada penelitian ini, kandungan alkali bebas yang tidak berlebihan diduga menyebabkan susu sapi yang ditambahkan pada sabun mandi tidak menyebabkan iritasi.

Pada umumnya, sabun berguna untuk menghilangkan kotoran, tetapi seperti yang telah disebutkan, sabun juga mempunyai beberapa efek yang tidak diharapkan. Efek yang tidak diharapkan tersebut dapat berupa kerusakan pada fungsi pertahanan kulit, yang dapat disebabkan karena senyawa iritan dan antigen, serta efek iritasi kulit yang ditandai dengan eritema dan udema. Eritema kulit merupakan kondisi kemerahan pada kulit sebagai hasil dari stimulus eksternal, reaksi imunologi, atau infeksi virus. Eritema dapat terjadi secara cepat setelah diberikan stimulus dan diintepretasikan sebagai reaksi refleks pada akson sistem saraf aferen. Setelah antigen menstimulus serat kulit sehingga mengaktifkan neuropeptida P/ Calcitonin Gene-Related Peptide (CGRP), yang kemudian dapat menginduksi vasodilatasi, sehingga meningkatkan aliran darah ke kulit dan menyebabkan kemerahan. ${ }^{18}$ Udema ditandai dengan adanya pembengkakan yang diawali dengan pembuluh darah kapiler tubuh mengalami kebocoran cairan dan cairan tersebut tersimpan di sekitar jaringan. Beberapa penyebab udema umumnya antara lain adalah sengatan lebah, infeksi kulit, reaksi alergi. ${ }^{20}$ Pada penelitian ini, sabun batang yang mengandung susu sapi tidak menyebabkan terjadinya iritasi dan udema.

\section{KESIMPULAN}

Hasil studi in vivo sabun mandi batang yang mengandung susu produksi UKM di Kelurahan Cipageran, Kecamatan Cimahi Utara, Kota Cimahi pada tikus Wistar, masuk kategori iritasi sangat ringan (negligigle). 


\section{UCAPAN TERIMA KASIH}

Ucapan terimakasih ditujukan pada Badan Penelitian dan Pengembangan Kota Cimahi dan Universitas Jenderal Achmad Yani yang membiayai penelitian ini melalui Program Kerjasama Penelitian Tahun 2019.

\section{DAFTAR RUJUKAN}

1. Riwayati I, Hartati I, Darmanto, Subekti E. Pemanfaatan susu sapi perah melalui diversifikasi produk olahan menjadi sabun mandi susu (Ipteks bagi masyarakat petanipeternak di desa Terwidi Gunung Pati Semarang). Techno. 2015;16(1):50-7. doi: 10.30595/techno.v16i1.66

2. Sumanto. Diversifikasi produk pengolahan susu guna meningkatkan keuntungan usaha kambing perah (milk products diversification to increase profit of dairy goat farming. Wartazoa. 2016;26(4):173-82.

3. Susanti AD, Astuti RD, Cahyono SI. PKM : Produksi sabun susu padat di Kelompok Wanita Ternak (KWT) Margomulyo Klaten. Prosiding Seminar Nasional Hasil Penelitian dan Pengabdian pada Masyarakat IV Tahun 2019 "Pengembangan Sumberdaya menuju Masyarakat Madani Berkearifan Lokal" LPPM - Universitas Muhammadiyah Purwokerto. 2019:568-73

4. Republik Indonesia. Peraturan Badan Pengawas Obat dan Makanan Nomor 23 Tahun 2019 tentang Persyaratan Teknis Bahan Kosmetik. Badan Pengawas Obat dan Makanan; 2019.

5. Ryder K, Ali MA, Carne A, Billakanti J. The potential use of dairy by-products for the production of non-food biomaterials. Critical Reviews in Environmental Science Technology. 2017;47(8):621-42. doi: https://doi.org/10.1080/ 10643389.2017.1322875

6. Cosentino C, Elshafie H, Labella C, D'Adamo C, Pecora G, Musto M, et al. Study on the protective effect of an innovative cow milk-based product against some human skin-bacterial pathogens. Journal of Biological Research. 2018;91(7426):35-9.

7. Standar Nasional Indonesia (SNI) 3532:2016 sabun mandi padat. Jakarta: Badan Standardisasi Nasional; 2016.

8. Retnowati DS, Kumoro AC, Ratnawati, Budiyati CS. Pembuatan dan karakterisasi sabun susu dengan proses dingin. Jurnal Rekayasa Proses. 2013;7(2):46-51. doi: https://doi.org/10.22146/jrekpros.4951

9. Ismanto SD, Neswati $\mathrm{N}$, Amanda $\mathrm{S}$. Pembuatan sabun padat aromaterapi dari minyak kelapa murni (virgin coconut oil) dengan penambahan minyak gubal gaharu (Aquilaria malaccensis). Jurnal Teknologi Pertanian Andalas. 2016;20(2):9-19. doi: https://doi.org/10.25077/jtpa.20.2.918.2016

10. Draelos ZD. The science behind skin care: cleansers. Journal of Cosmetic Dermatology. 2018;17(1):8-14. doi: https://doi.org/10.1111/jocd.12469

11. Félix S, Araújo J, Pires AM, Sousa AC. Soap production: a green prospective. Waste Management. 2017;66:190-5. doi: 10.1016/j.wasman.2017.04.036

12. Vidal NP, Adigun OA, Pham TH, Mumtaz A, Manful C, Callahan G, et al. The effects of cold saponification on the unsaponified fatty acid composition and sensory perception of commercial natural herbal soaps. Molecules. 2018;23(9):1-20. doi: https://doi.org/10.3390/molecules23092356

13. Republik Indonesia. Peraturan Kepala Badan Pengawas Obat dan Makanan Republik Indonesia No. 7 Tahun 2014 tentang Pedoman Uji Toksisitas Nonklinik Secara In vivo. Badan Pengawas Obat dan Makanan; 2014.

14. Khosrowpour Z, Nasrollahi SA, Ayatollahi A, Samadi A, Firooz A. Effects of four soaps on skin trans-epidermal water loss and erythema index. Journal Cosmetic Dermatology. 2019;18(3):85761. doi: 10.1111/jocd.12758

15. Marangoni F, Pellegrino L, Verduci E, Ghiselli A, Calvani R, Cetin I, et al. Cow's milk consumption and health: a Health Professional's guide. Journal of the American College of Nutrition. 2018;0(0):1-12. doi: https://doi.org/10.1080/07315724.2018.149 1016

16. Blaak J, Staib P. The relation of $\mathrm{pH}$ and skin cleansing. in: $\mathrm{pH}$ of the skin: issues and Challenges. 2018;(54):132-42. doi: https://doi.org/10.1159/000489527

17. Baranda L, Amaro RG, Alvarez BT, Alvarez C, Ramírez V. Correlation between $\mathrm{pH}$ and irritant effect of cleansers marketed for dry skin. International Journal Dermatology. 2002;41(8):494-9. doi: 
10.1046/j.1365-4362.2002.01555.x

18. Abdlaty R, Fang Q. Skin erythema assessment techniques: review article. [Internet]. ResearchGate: 2018 September 18. doi: 13140/RG.2.2.13101.54245 